\title{
Frédéric Duval, La philologie française, pragmatique avant tout? L'édition des textes médiévaux français en France
}

Maria Colombo Timelli

\section{(2) OpenEdition}

Journals

Édition électronique

URL : http://journals.openedition.org/studifrancesi/9413

DOI : $10.4000 /$ studifrancesi.9413

ISSN : 2421-5856

Éditeur

Rosenberg \& Sellier

Édition imprimée

Date de publication : 1 décembre 2007

Pagination : 621

ISSN : 0039-2944

\section{Référence électronique}

Maria Colombo Timelli, « Frédéric Duval, La philologie française, pragmatique avant tout? L'édition des textes médiévaux français en France », Studi Francesi [En ligne], 153 (LI | III) | 2007, mis en ligne le 30 novembre 2015, consulté le 11 janvier 2021. URL : http://journals.openedition.org/studifrancesi/9413 ; DOI : https://doi.org/10.4000/studifrancesi.9413

Ce document a été généré automatiquement le 11 janvier 2021.

\section{cc) $($ ) $\ominus$}

Studi Francesi è distribuita con Licenza Creative Commons Attribuzione - Non commerciale - Non opere derivate 4.0 Internazionale. 


\title{
Frédéric Duval, La philologie française, pragmatique avant tout? L'édition des textes médiévaux français en France
}

\author{
Maria Colombo Timelli
}

\section{RÉFÉRENCE}

FRÉDÉRIC DUVAL, La philologie française, pragmatique avant tout? L'édition des textes médiévaux français en France, «Études et rencontres de l'École des Chartes», 21, Pratiques philologiques en Europe, 2006, pp. 115-150.

1 F.D. propose une réflexion stimulante sur la pratique éditoriale française au cours de ces dernières décennies. Dans un premier volet il s'attache aux aspects théoriques, en soulignant surtout l'absence de discussions méthodologiques en France depuis Bédier. Il souligne ensuite les contradictions dans la pratique ecdotique: les éditions françaises, œuvres pour la plupart de littéraires qui ne sont ni philologues ni linguistes de formation, se distinguent par une attention marquée pour les aspects littéraires des textes édités et en revanche par un traitement superficiel, et souvent archaïque, des questions linguistiques. Dans une telle pratique, les problèmes philologiques, qui devraient fonder tout travail d'édition, sont souvent négligés ou sous-estimés. Résultat complexe d'un héritage ancien, de conditions de publication lourdes de conséquences (le panorama éditorial fait l'objet d'un paragraphe éclairant), d'une situation académique particulière, les pratiques éditoriales françaises doivent être connues de tout lecteur sensible à la qualité scientifique des textes mis à sa disposition. 